\title{
NOVAS POLITICAS DE RECURSOS HUMANOS: SEUS IMPACTOS NA SUBJETIVIDADE E NAS RELAÇÕES DE TRABALHO
}

Os resultados de uma pesquisa realizada em grande empresa brasileira pioneira na introdução de novas políticas de Recursos Humanos.

The findings of a research carried out in a Brazilian enterprise which can be seen as pionner in the introduction of new human resources policies.

\section{PALAVRAS-CHAVE:}

Novas Políticas, dualismo so-

cial, racionalidade instrumen-

tal, modelo japonês, relações de trabalho.

\section{KEY WORDS:}

New policies, social dualism, instrumental rationality, Japanese model, industrial relations.

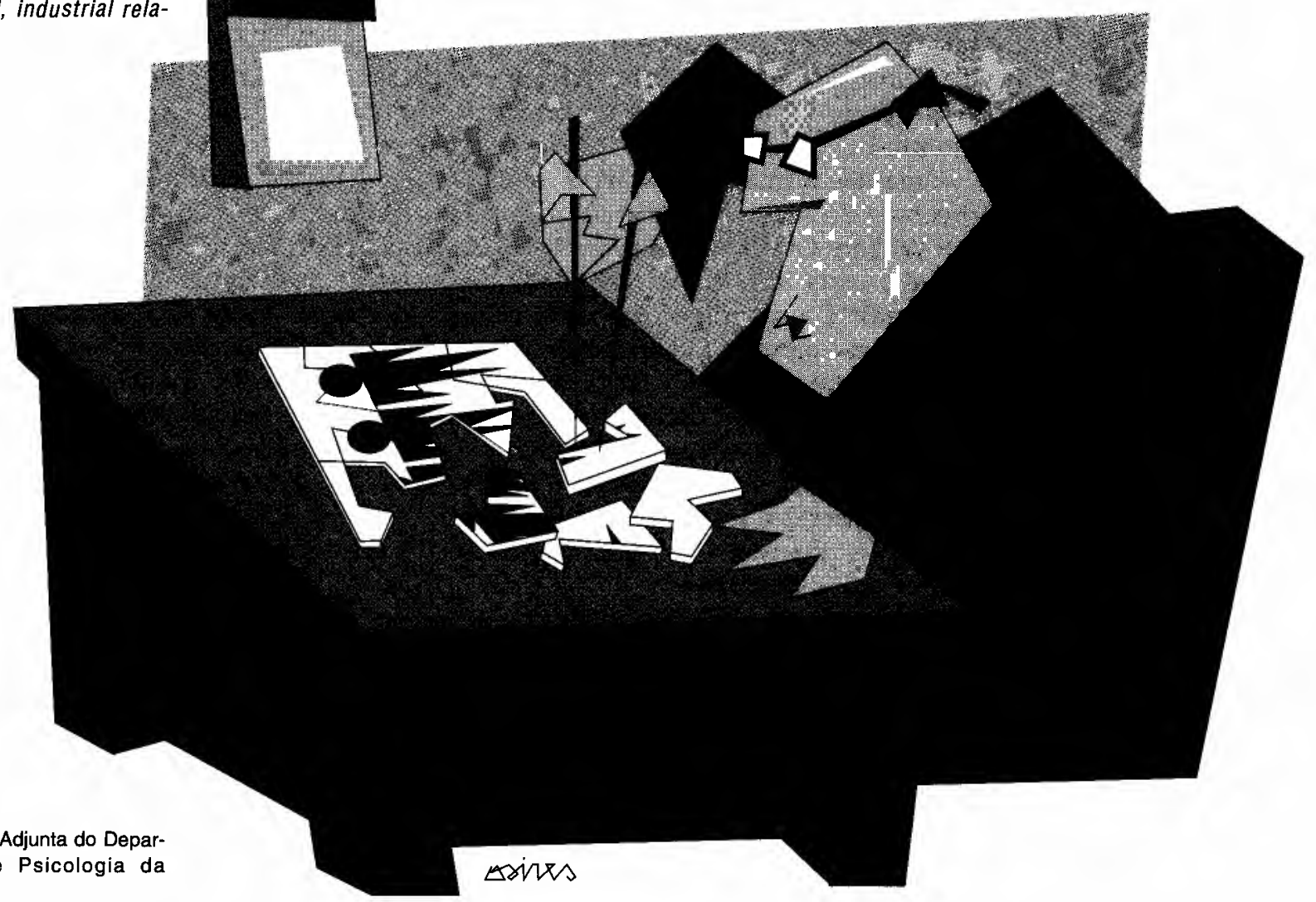


Apesar de recorrer aos princípios de antigas teorias administrativas, as políticas de pessoal, adotadas por um grande número de empresas ocidentais no decorrer dos últimos anos, apresentam-se como inovadoras. Com efeito, por trás de um discurso mais sofisticado e pretensamente científico, é possível identificar as principais formulações de antigas teorias administrativas como a Teoria de Relações Humanas, a Teoria Estruturalista, a Teoria Comportamental, dentre outras. $\mathrm{O}$ que nos parece representar uma novidade é a considerável generalização dessas antigas idéias, isto é, sua grande aceitação e conseqüente aplicação por um número cada vez maior de empresas, no decorrer dos últimos anos.

A entrada dos produtos japoneses no mercado mundial e as crises do petróleo têm sido apontadas como as duas principais causas da expansão desta "nova" prática gerencial. Realmente, após a entrada massiva de produtos japoneses no ocidente, ameaçando economias até então hegemônicas, a preocupação central dentro da administração tem sido a de decifrar o segredo tão bem guardado pelo Japão e que lhe permitiu, não apenas recuperar rapidamente sua economia, totalmente destruída após a Segunda Guerra, como também provocar desequilíbrios importantes no mercado mundial.

Uma das primeiras tentativas de compreensão do sucesso japonês foi realizada por William Ouchi, no best seller Teoria Z. ${ }^{1}$ $A$ idéia mais importante veiculada por este autor é a de que é possível realizar uma sintese entre os modelos administrativos oriental e ocidental. Segundo ele, as empresas mais lucrativas do ocidente são aquelas que já realizaram esta síntese. Muitos autores lhe sucederam e a idéia de se importar o modelo administrativo japonês permanece, com ligeiras modificações, até os dias atuais.

No entanto, é preciso citar uma outra

1. OUCHI, W. Théorie $Z$ - faire face au défi japonais. Paris: Intereditions, 1979.

2. MESSINE, Ph. Les saturniens - quand les patrons reinventent la société. Paris: La Découverte, 1987.

3. Idem, ibidem. corrente dentro da administração contemporânea, composta por críticos à importação do Modelo Japonês. O modelo preconizado pelos autores desta corrente baseia-se numa experiência realizada pela General Motors, denominada Projeto Saturno. Evidentemente, esse projeto foi também concebido para se enfrentar a concorrência japonesa. No entanto, em vez de tentar a síntese dos dois modelos (aderindo, assim, à corrente chamada "californiana") a idéia do Projeto Saturno era a de inaugurar uma nova prática gerencial, diferente de tudo o que havia sido feito até então. Apesar da busca de originalidade, a maior novidade neste segundo modelo consiste na tentativa de se criar um novo pacto social, negociado com os sindicatos, ao invés da hostilidade aberta contra a ação sindical manifestada pelas empresas "californianas". Além disso, na empresa "saturniana", as divergências e conflitos são considerados inevitáveis e por isso devem ser tratados de forma aberta e negociada para se obter o consenso. A forma de controle é que se modifica: "O empregador saturniano se serve das negociações coletivas como um meio de se informar sobre o que se passa na fábrica". ${ }^{2}$

Percebe-se, no entanto, que o sindicalismo aceito e preconizado por este modelo identifica-se exatamente com aquele do qual tenta se afastar, ou seja, o "sindicalismo à japonesa". É o próprio Messine, um dos apologistas deste modelo, que nos oferece o melhor argumento quando afirma: "É preciso reduzir a função tradicional do sindicato relativa à negociação salarial, para privilegiar um sindicalismo de proposição, totalmente voltado para a eficácia operacional. Esta reorientação significa o abandono progressivo de um sindicalismo nacional ou por categoria, em proveito de um sindicalismo por empresa. Enquanto o primeiro fixa as normas salariais e, por natureza, ignora os problemas específicos de cada empresa considerada individualmente, o segundo se presta bem a uma integração funcional à japonesa" ${ }^{3}$

Portanto, as políticas de pessoal que têm sido adotadas por um número significativo de empresas ocidentais baseiam-se, direta ou indiretamente, no que convencionamos chamar de Modelo Japonês. Aquelas que possuem os recursos necessários conseguem importar este modelo de maneira bastante fiel, enquanto que às outras resta apenas a possibilidade de um arremedo grotesco, como temos presenciado através da recente generalização dos programas de Qualidade Total. As políticas adotadas pelas primeiras empresas, isto é, aquelas que conseguiram importar de maneira mais fiel o Modelo Japonês, podem ser assim resumidas: estabilidade 
no emprego, salário acima da média do mercado, grande investimento na formação dos empregados e na inovação tecnológica, maior polivalência dos trabalhadores, busca da adesão do sindicato aos objetivos da empresa, criação de um "mercado interno", isto é, elaboração de um plano de carreira que permite a ascensão funcional, incentivo à participação dos empregados nas decisões relativas ao seu setor de trabalho, maior autonomia e maior controle do processo de trabalho por parte dos trabalhadores, redução dos níveis hierárquicos e fragmentação da empresa em pequenas unidades com a finalidade de facilitar seu controle.

No presente artigo pretendemos discutir os resultados de uma pesquisa realizada numa grande empresa brasileira do setor metalúrgico, que importou de maneira bastante fiel as práticas gerenciais japonesas. ${ }^{4}$ Esta pesquisa tinha por objetivo estudar os impactos destas políticas sobre a subjetividade dos empregados. O enfoque especial dado aos aspectos subjetivos deve-se não somente à carência de estudos neste campo, como também e, principalmente, à idéia de que estas novas práticas gerenciais atingem de forma privilegiada a vida psíquica, ao contrário de algumas das antigas práticas que tinham no corpo seu alvo maior. Não podemos nos esquecer que, se os fundamentos de tais políticas podem ser identificados em antigas teorias administrativas, a sua versão atualizada vem enriquecida pelas descobertas mais recentes da Psicologia, além daquelas realizadas por outras disciplinas como a Sociologia, a Economia e a própria Administração. Isto significa que nesta nova versão, antigas práticas de Relações Humanas, por exemplo, ficam potencialmente mais perigosas, pois são enriquecidas pelas descobertas mais recentes realizadas pelas Ciências Humanas, notadamente pela Psicologia.

\section{AS NOVAS POLÍTICAS DE PESSOAL NO BRASIL - CONTEXTO SÓCIO-HISTÓRICO}

As políticas de Recursos Humanos, adotadas nos últimos anos por um número cada vez mais significativo de empresas brasileiras, baseiam-se em modelos propostos pelas empresas mais lucrativas do Primeiro Mundo, que, por sua vez, têm encontrado no Modelo Japonês a sua fonte máxima de inspiração. O sucesso destas empresas - cujos resultados econômicos representam o parâmetro de avaliação mais importante - é freqüentemente atribuído por seus dirigentes e por seus ideólogos ao tipo de política que elas adotaram.

Algumas das grandes empresas brasileiras já tinham inovado suas políticas, mas a discussão só se ampliou realmente após a publicação do livro Virando a própria mesa. ${ }^{5}$ Com efeito, pela primeira vez no Brasil um livro sobre política empresarial interessou até mesmo às pessoas que não estavam diretamente vinculadas às empresas. Este livro esteve na lista dos mais vendidos durante cerca de três anos, o que reforça a sua importância no novo cenário que se delineava. Um dos objetivos revelados por este empresário ao transformar suas políticas de pessoal era $o$ de tornar a empresa um lugar atraente, onde as pessoas se sentissem bem e gostassem de trabalhar. Para ele, a gestão da empresa depende essencialmente da relação de confiança que se estabelece entre patrão e empregado. É por esta razão que inicia a transformação de sua empresa pela eliminação de alguns dispositivos tradicionais de vigilância e de controle dos empregados: o controle do ponto, isto é, o controle dos horários de entrada e de saída e a revista dos empregados na saída da empresa. Além disso, Semler percebia o modelo gerencial anterior como paternalista e autoritário, pois não suportava qualquer sugestão ou reivindicação dos trabalhadores. Segundo ele, os antigos dirigentes consideravam qualquer reivindicação ou sinal de insatisfação como uma ofensa pessoal. Tratava-se, portanto, da necessidade urgente de "profissionalizar" a empresa, isto é, de separá-la radicalmente da vida pessoal dos seus proprietários e empregados. Desta forma, ela não seria mais considerada como uma extensão da vida familiar e as reivindicações passariam a ser aceitas naturalmente, como algo inerente à toda vida organizacional.

Se este discurso não traz nada de realmente novo para quem tem acompanhado o desenvolvimento das políticas de pessoal adotadas pelas empresas, ele é rico em esperanças para aqueles que sempre se submeteram a modelos autori-
4. Os resultados desta pesquisa serviram de subsídios para a elaboração de nossa tese de doutorado, intitulada Effets psychopathologiques des nouvelles politiques de ressources humaines, defendida na Universidade Paris IX, em junho de 1992.

5. SEMLER, R. Virando a própria mesa - um sucesso empresarial made in Brazil. São Paulo: Best Seller, 1988. 
6. Idem, ibidem

7. O próprio Semler não é uma exceção. Ele deixa claro no seu livro que as dificuldades econômicas vividas por sua empresa durante os anos 80 impunham uma mudança imediata. Além disso, é ele mesmo quem confessa que um modelo tradicional de gestāo nẵo teria possibilitado o pagamento dos empréstimos que foi obrigado a fazer para salvar sua empresa.

B. CHASIN, J. A sucessão na crise e a crise na esquerda. Revista Ensaio, Sāo Paulo, 1989. tários e/ou tradicionais de gestão. Ele dá uma ênfase especial à "humanização das relações de trabalho", reforçando a necessidade de reconhecer e valorizar o empregado como um ser humano. É Semler quem constata o esforço realizado pelas empresas atuais para "encontrar um modo de tratar este novo ser humano que insiste em ser tratado como tal". ${ }^{\prime \prime}$

O livro de Semler passa a idéia de que sua empresa encarna a fórmula mais acabada de "democracia empresarial", especialmente quando toca no ponto mais delicado da relação capital/trabalho, reconhecendo a importância do sindicato e da participação dos trabalhadores nas atividades sindicais ou nas comissões de fábrica. As políticas que preconiza podem ser facilmente assimiladas àquelas identificadas anteriormente como modelo "saturniano". Apesar da tentativa de se apresentar o modelo gerencial como tipicamente brasileiro, o subtítulo escolhido para o livro trai suas verdadeiras origens: "um sucesso empresarial made in Brazil".

As idéias que prevalecem em torno dessas novas políticas não resistem a uma análise mais cuidadosa. As freqüentes contradiçōes revelam as verdadeiras razões que levam os empresários a adotar este ou aquele modelo, desmantelando toda a aparente coerência desse discurso que fala de um "novo humanismo na empresa" baseado numa "verdadeira experiência democrática". Percebe-se, invariavelmente, a importância crucial dos resultados econômicos, apesar da tentativa freqüente de se dissimular ou minimizar este dado. Normalmente são as dificuldades econômicas vividas pela empresa que levam à modificação de suas políticas de pessoal. ${ }^{7}$ Em alguns casos, a empresa se antecipa a estas possíveis dificuldades, inovando suas políticas que, neste caso, teriam uma função preventiva. Em outros, ela simplesmente opta por um novo modelo com a finalidade de tornar-se mais competitiva e conquistar novos mercados.

Além disso, por trás de um discurso que preconiza a participação e a democracia industrial, o que vemos é um "participacionismo" e a "democracia" é o universo de sua realização. Esta espécie de "democracia" - colocada como a forma suprema de liberdade - não passa na verdade da busca incansável do consenso,

da "harmonia de interesses individuais e organizacionais". Um autor que aborda de forma pertinente esta questão é J. Chasin. Ele fala da diferença fundamental entre participacionismo e a verdadeira democracia afirmando que o primeiro se baseia no estrangulamento das contradições pela administração ou pela força, enquanto que a segunda dá livre curso a estas contradiçōes para que possam ser explicitadas e depois resolvidas, não pela simples participação política, mas pela

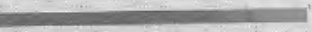

Se este discurso não traz nada de realmente novo para quem tem acompanhado o desenvolvimento das políticas de pessoal adotadas pelas empresas, ele é rico em esperanças para aqueles que sempre se submeteram a modelos autoritários e/ou tradicionais de gestão.

intervenção social. A democracia se dcfine para ele como um campo de batalha aberto na busca de soluçōes que a ultrapassam e não simplesmente como uma instância de participaçōes resolutivas que a reiteram. ${ }^{8}$

A reivindicação é valorizada e considerada como legítima, mas é preferível que seja expressa por um grupo interno da empresa, criado para esta função, do que ser imposta por um acordo de greve, por exemplo. Apesar de todo um discurso favorável à expressão de conflitos e de reivindicações, Semler deixa bem claro que a greve é "um movimento de agressão à empre$s a^{\prime \prime}$ e por isto nāo deve haver negociação em estado de greve. A sua preocupação com a antecipação dos conflitos fica evidente quando diz que "o corpo de funcionários percebe que a greve não é necessária se souber usar os mecanismos de diálogo da empresa para se manifestar". Ele sugere, enfim, que todo assunto - inclusive o salário seja discutido dentro da hierarquia e das comissões de fábrica para evitar que "este 
tópico acabe virando assunto de greve". Uma frase sua resume bem o verdadeiro objetivo de suas políticas: "a desobediência civil na empresa deve ser sutilmente encorajada... O bom senso requer um pouco de desobediência civil para alertar a organização de que alguma coisa não vai bem". Desta forma, a empresa pode ser alertada sobre as insatisfações e os conflitos antes que eles possam "virar assunto de greve". 9

Apesar disso, este discurso foi muito bem recebido em nossa sociedade: de um lado, a população em geral vê neste modelo o nascimento de uma nova relação, mais justa e mais humana, entre capital e trabalho, ou até mesmo a solução mágica às contradições e aos conflitos sempre presentes nesta relação e considerados até então como insolúveis; de outro lado, os empresários vêem nele a resposta aos problemas econômicos vividos por suas empresas. Aqueles que colocam em prática estas políticas são percebidos como verdadeiros pioneiros na humanização da empresa no Brasil. Além disso, eles foram capazes de solucionar problemas muito graves e antigos sem provocar mudanças drásticas na ordem das coisas. ${ }^{10}$ Enfim, estes empresários são percebidos como extremamente habilidosos, pois foram capazes de encontrar medidas que satisfaziam plenamente todos os participantes da organização, assegurando assim a paz social e organizacional. E tudo isso não impede mas ao contrário, favorece - a rentabilidade crescente da empresa. Este é um dos seus maiores méritos: conseguir aumentar cada vez mais os lucros sem que isto implique o tratamento injusto e desumano de seu pessoal. Eles lhe concedem, pelo contrário, vantagens materiais e psicológicas que as outras empresas jamais pensaram em introduzir nas suas políticas.

Um outro elemento importante para compreendermos a expansão dessas novas políticas de pessoal no Brasil diz respeito a algumas medidas adotadas pelo governo Collor. Um documento elaborado por Zélia Cardoso de Mello e seus assessores é bastante revelador do desejo deste governo de colocar em prática um plano de modernização das empresas. ${ }^{11}$ Esta idéia de modernização esteve presente durante toda a campanha presi- dencial, onde associava-se à imagem de um jovem audacioso e dinâmico, naturalmente o único capaz de levá-la a termo. Modernizar significava, antes de mais nada, integrar o Brasil ao Primeiro Mundo. Este é apresentado como o exemplo maior de sucesso e como o paraíso das conquistas materiais, em especial, graças ao funcionamento da economia de mercado sem interferência do Estado. Se o mercado é soberano, a abertura total da economia aparece como a única saída possível ao subdesenvolvimento. Segundo Barelli, "As dificuldades da economia brasileira são atribuídas à intervenção excessiva do Estado e à fraca exposição da economia ao exterior. Ao liberar as exportações, $a$ indústria brasileira seria obrigada a se modernizar e a incorporar as novas tecnologias, sob pena de não poder enfrentar a concorrência internacional" ${ }^{12}$ Concordamos com este autor quando ele fala da extrema fragilidade deste argumento que negligencia "o fato de que a atual divisão internacional do trabalho tem suas próprias regras no que se refere aos capitais $e$ à tecnologia, e que não é suficiente abrir a economia para conquistar posições no mundo contemporâneo". ${ }^{13}$ Além disso, não podemos deixar de perceber, neste tipo de discurso, o que Mappa ${ }^{14}$ considera como a melhor ilustração da racionalidade instrumental, isto é, "a questão do como alcançar o trem do desenvolvimento domina aquela do porque, para quem e qual desenvolvimento".

Foi, portanto, com este objetivo vago de "modernização industrial" no Brasil que um grupo de técnicos do Ministério da Economia elaborou em 1990 o documento citado anteriormente e que merece ser rapidamente descrito. Para eles, a modernização das indústrias brasileiras depende da adoção de modernos métodos de gestão da produção e de gestão tecnológica, assim como da capacidade de incorporar novas tecnologias. Para isto, o essencial é a "qualidade e a produtividade" que são colocadas como "instrumentos estratégicos" para tornar possível "o crescimento econômico e o desenvolvimento social". Segundo eles, a política adotada pelo governo Collor, buscando reduzir a presença do Estado na atividade produtiva, tornava a economia competitiva em nível internacional e oferecia um
9. SEMLER, R. Op. cit.

10. Como diz o próprio Semler: "Não há sinal de revolução e de desautorização a caminho". SEMLER, R. Op. cit.

11. CARDOSO DE MELLO, Z. et al. A modernização industrial no Brasil, documento divulgado em 1990.

12. BARELLI, W. Le coût social de la modernisation conservatrice. Revue Mensuel, Marxisme, Mouvement. Paris, n. 42, 1990.

13. Idem, ibidem.

14. MAPPA, S. et al. Rapport de Synthèse de Forum de Delphes. Paris: Karphala, 1991. 
ambiente favorável à implementação dessas mudanças. Propõem, então, o Programa Brasileiro de Qualidade e de Produtividade que teria um pressuposto fundamental: "a ação harmoniosa e coordenada do Estado, dos empresários e dos consumidores". Eles criaram o Comitê Nacional de Qualidade e de Produtividade, que teria a função de estabelecer um conjunto de ações indutoras da modernização industrial e tecnológica no país, introduzindo, assim, o Brasil "no contexto das economias mais desenvolvidas".

Não poderíamos deixar de criticar uma visão tão simplista das economias dos países subdesenvolvidos. Estes técnicos consideram que a modernização industrial, baseada especialmente na preocupação com a qualidade e com a produtividade, será suficiente para elevar o Brasil ao nível dos países do Primeiro Mundo. Vários aspectos importantes estão ausentes nesta discussão, mas, em nossa opiniāo, o mais importante concerne ao fato de que nossa economia é dependente desde suas origens e que " $a$ mundialização do capital subsume formaçôes sociais distintas e engendra desenvolvimentos desiguais e combinados (...) Com ela não se processa, a não ser formalmente, (...) uma igualização internacional, mas a constituição de uma cadeia de elos muito desiguais, cuja dinâmica constitutiva, grau de configuração, capacidade de auto-sustentação e potência reprodutiva sāo profundamente distintos" ${ }^{15}$ Finalmente, concordamos plenamente quando Chasin afirma que "pela via colonial da objetivação do capitalismo o receptor tem de ser reproduzido sempre enquanto receptor, ou seja, em nivel hierárquico inferior na escala global de deservolvimento". 16

Em resumo, decidimos estudar uma dessas empresas, pois nos pareceu urgente e necessário desvendar as novas relaçōes de trabalho que estavam se delineando a partir da introdução dessa estratégia gerencial no Brasil. Nosso estudo foi basicamente qualitativo com uma amostra composta por três categorias socioprofissionais: operários, trabalhadores de escritório e executivos. Utilizamos quatro intrumentos para coleta de dados: uma adaptação do T.A.T. (teste projetivo de personalidade), uma entrevista individual semi-estruturada, um questionário e uma entrevista coletiva.

\section{DISCUSSÃO DOS RESULTADOS}

\section{As dimensões psicológicas}

Através do nosso estudo detectamos os seguintes impactos psicológicos provocados por estas novas políticas de pessoal: uma forte identificação dos empregados com a empresa e com seu projeto de dominaçāo, a idealizaçāo da empresa, favorecendo com freqüência a emergência de processos narcisistas (especialmente entre os empregados de escritório e os executi-

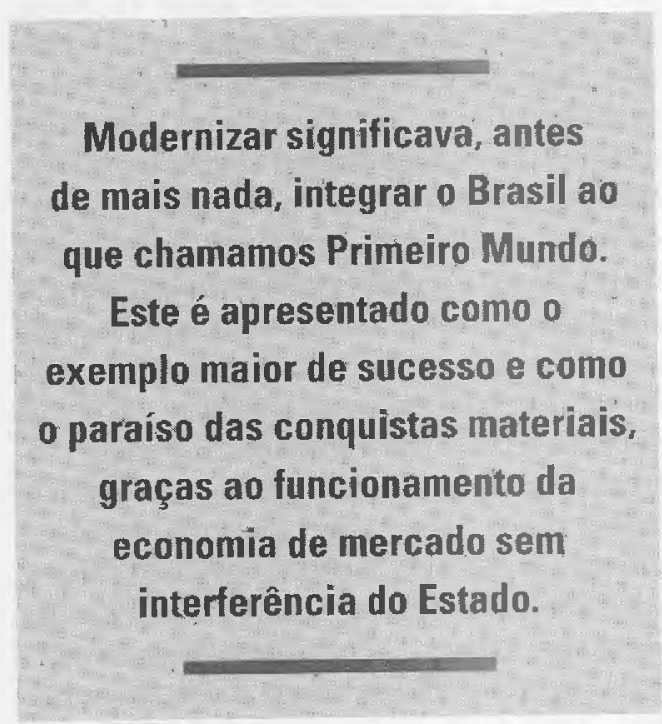

vos), a importante redução da capacidade de questionar e criticar a empresa, o crescimento da rivalidade entre os pares e, especialmente, entre aqueles que se encontram em um processo de mobilidade ascendente, a forte instrumentação das relaçōes interpessoais. Estes últimos reproduzem na relação com os subordinados ou com os pares a forte instrumentação presente nas políticas adotadas pela empresa e que é a própria essência da sua aplicação: o outro torna-se um mero instrumento para o alcance de suas próprias finalidades que são freqüentemente associadas ao projeto de carreira proposto pela empresa.

Afirmamos, anteriormente, que uma das causas principais da expansão dessas novas políticas concerne à crença no livre jogo de mercado como o único elemento regulador da oferta e da demanda. Sabemos que o neoliberalismo é, antes de mais nada, o retorno do velho tema da regulação econômica pelos mecanismos de mercado e da concorrência. Desta forma, fica legitimado o afrontamento de interesses, 
base de uma economia regida pelo mercado, e que se manifesta com mais clareza na concorrência entre capitalistas e na relação capital-trabalho. Observamos que as empresas que adotam estas políticas aderem a este princípio ao ponto de introduzir o "mercado" no seu próprio espaço interno. Na empresa estudada, esta prática, caracterizada notadamente por uma forte política de carreira, provoca uma violenta concorrência entre setores e indivíduos, cujos meios para vencer não diferem daqueles utilizados no mercado externo. Não nos parece muito difícil concluir que uma sociedade que considera legítimo o afrontamento de interesses e que, além disso, considera-o como a única maneira de alcançar a ordem e o equilíbrio, legitime, ao mesmo tempo, certas condutas pouco conformes à ética, como, por exemplo, a relação instrumental com o outro. Não se trata, portanto, de um mero acaso à forte presença deste comportamento nos resultados obtidos, especialmente entre aqueles que se dispõem a entrar na corrida pela ascensão e que, portanto, participam mais ativamente do jogo proposto pela empresa. Em nossa opinião, este jogo não passa de uma recuperação, por parte da empresa, das práticas mais comuns na sociedade contemporânea, e o Brasil não representa, de maneira nenhuma, uma exceção.

Nosso objeto de estudo era, essencialmente, os impactos dessas novas políticas sobre a subjetividade dos empregados. Percebemos que essas novas práticas gerenciais não são de modo algum inocentes e que elas repercutem negativamente, não só na vida psíquica dos indivíduos, mas também no campo social. ${ }^{17} \mathrm{E}$ importante sublinhar que todas estas considerações não nos impedem de reconhecer os aspectos positivos presentes nessas políticas: a maior valorização econômica dos empregados, que se reflete na política de altos salários, o maior espaço para inovação e participação, o enriquecimento do conteúdo de algumas funções, a maior segurança no emprego, as relações hierárquicas menos despóticas etc. No entanto, não podemos nos esquecer de que todas estas vantagens representam ao mesmo tempo um perigo, pois a maioria das pessoas que se submetem a tais políticas manifestam um forte apego aos privilégios que lhes são concedidos, tornando-se ex- cessivamente dependentes e pouco críticas em relação à empresa. Existe, portanto, um preço a ser pago pela participação em um grupo tão privilegiado.

Um outro resultado que nos parece importante diz respeito à amplificação ou até mesmo à imposição de estratégias defensivas por essas políticas. Certos tipos de mecanismos de defesa (idealização, identificação, recusa da realidade, clivagem, repressão etc.), ${ }^{18}$ assim como certos comportamentos defensivos (individualismo, relação instrumental com o outro etc.), pareceram-nos ampliados e, às vezes, adotados com muito esforço pelo sujeito para responder às pressões típicas dessas empresas. Estas pressões são, essencialmente, as exigências excessivas de produtividade e de qualidade, a forte competição entre pares, as injunções paradoxais e as contradições (facilmente observadas nos seus princípios), além do imperativo de autosuperação. É importante esclarecer que a intensificação exacerbada de mecanismos psicológicos de defesa é considerada como elemento importante nos processos de ruptura da estabilidade psíquica, o que reforça a nossa hipótese de que a situação criada por estas políticas envolve riscos mentais significativos.

Além disso, observamos uma estreita relação entre a função afetiva preenchida pela família de origem e o tipo de relação que o sujeito irá estabelecer com a empresa que adota estas políticas. Nossos resultados sugerem fortemente que aqueles que viveram relações originárias pouco afetivas se mostravam mais dispostos a aceitar o discurso dessas empresas e a se identificar com elas. Em resumo, a maior parte dos indivíduos que tiveram pouco afeto na família tentam recriar este afeto, seja com a empresa, seja com o superior hierárquico. Aqueles que tiveram segurança afetiva na família mostraram-se sempre capazes de estabelecer uma boa distância em relação à empresa e de lhe dar uma dimensão mais real. Nossos resultados nos permitem concluir que os impactos dessas políticas diferem segundo a categoria socioprofissional na qual se encontra o sujeito, mas têm igualmente uma relação com a sua história pessoal e com o perfil psicológico que dela resulta.

É igualmente importante salientar que nossa análise centrou-se sobre o sujeito e
17. Alguns autores (I. Hoffman em seu artigo Les managers et le capitalism; J. Palmade, no artigo Management post-moderne ou la technocratisation des sciences de l'homme, dentre outros) têm alertado sobre a possibilidade de que estas práticas ultrapassem o espaço da empresa, invadam o espaço social e reforcem, desta maneira, suas tendências autoritárias. Nossas primeiras observações sobre a forma pela qual os programas de Qualidade Total têm penetrado em outros setores, como a educação e a saúde, revelam-nos que esta previsão pode, infelizmente, ser correta.

18. Os mecanismos de defesa são compreendidos como "diferentes tipos de operação" elaborados pelo ego, através dos quais 0 sujeito afronta os conflitos. A idealização é um "processo psíquico através do qual as qualidades e 0 valor do objeto são elevados à perfeição". A clivagem é definida como uma forma de defesa através da qual 0 objeto é cindido em "bom" e "mau". A identificação é definida como "um processo psicológico pelo qual um sujeito assimila um aspecto, uma propriedade, um atributo do outro e se transforma, total ou parcialmente, em seu modelo". LAPLANCHE, J., PONTAL.IS, J. Vocabulaire de la Psychanalyse. Paris: PUF, p. 67 e 186-87,1967. 
19. ElGHER, A. Le pervers narcissique et son complice. Paris: Dunod, 1989

20. Empregamos aqui o mesmo termo utilizado por Enriquez para designar as empresas que colocam em prática essas novas políticas de pessoal, isto é, aquelas que adotam um modelo gerencial que tem por objetivo aumentar seus resultados econômicos, mas tentando dissimular este objetivo através de um discurso fortemente ideológico que coloca o bem-estar dos indivíduos acima de qualquer outro valor. Elas tentam também nos convencer de que suas decisões baseiam-se unicamente em critérios éticos, s0ciais e/ou estéticos. Segundo este discurso, os resultados econômicos alcançados pela empresa são uma conseqüência, ou atẻ mesmo uma recompensa, de sua prática humanista. Em nossa opiniāo, estas politicas tornaram-se um componente muito importante das estratégias adotadas pela empresa para poder enfrentar as pressões do mercado. ENRIQUEZ, E. L'individu pris au piège de l'entreprise stratégique. Paris, $R e$ vue Conexions, v. 54, 1989-2. suas possibilidades de defesa e de resistência. Neste aspecto, nosso estudo se distancia de outros realizados neste domínio: ao contrário da concepção dominante neste tipo de análise, partimos da idéia de que o sujeito é capaz de analisar sua situação de trabalho e de encontrar a melhor forma de enfrentar as dificuldades e pressões aí existentes. Ele não é um "joguete passivo", "modelado" pela empresa, mas mostra-se, ao contrário, freqüentemente capaz de mobilizar uma energia considerável a fim de atingir um certo equilíbrio e alcançar uma certa adaptação às pressões impostas por essas políticas. É importante salientar que este equilíbrio é precário e que ele se torna mais precário à medida que o sujeito se aproxima do topo da pirâmide. Concluímos, portanto, que os meios de proteção contra os efeitos nefastos desta prática gerencial são tanto mais frágeis quanto mais o sujeito se encontra próximo do alto da hierarquia. Logo, foram os altos executivos que se mostraram mais vulneráveis a estes efeitos.

Finalmente, um outro resultado que merece ser discutido aqui concerne aos eventuais distúrbios da subjetividade e da intersubjetividade que estas novas políticas podem desencadear ou reforçar. Ao iniciarmos a pesquisa, nossa hipótese era a de que tais políticas teriam um efeito amplificador ou mesmo catalisador destes distúrbios. No entanto, nossos resultados nos permitiram ir além; pensamos, então, no favorecimento à constituiçāo de novos distúrbios e não apenas na amplificação daqueles que o sujeito já apresentava ao chegar à empresa. Parece-nos importante ressaltar que estes efeitos diferem segundo a categoria socioprofissional na qual se encontra o sujeito. Assim, pertencer a uma categoria socioprofissional onde seja possivel encontrar uma fonte de valores comuns, atividades mais objetiváveis e relações mais afetivas e solidárias, revelou-se um elemento fundamental na compreensão do modo pelo qual o sujeito irá enfrentar essas políticas.

Constatamos igualmente uma dificuldade bastante generalizada na percepção do conflito e uma forte tendência a esquematizar a realidade, ou seja, a reduzir (ou mesmo negar) sua complexidade. Em outras palavras, percebemos que as três categorias estudadas tendem a simplificar o real, a eliminar da consciência seus conflitos e contradições, sendo que tal tendência se intensifica à medida que o sujeito se aproxima do topo da hierarquia. Além disso, o discurso paradoxal e contraditório é igualmente comum, apesar de ser mais explicito entre aqueles que querem ser os intérpretes da ideologia da empresa, como os altos executivos, por exemplo. Em nossa opinião, estes resultados podem ser, em grande parte, atribuídos ao longo tempo de exposição destes indivíduos à comuni-

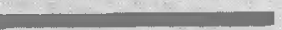

Percebemos que essas novas práticas gerenciais não são de modo algum inocentes e que elas repercutem negativamente, não somente sobre a vida psíquica dos indivíduos, mas começam a estender seus efeitos nefastos sobre o campo social.

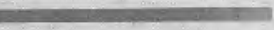

cação paradoxal. Não pudemos nos esquecer que a estabilidade dos empregados neste tipo de empresa é muito grande, não somente pela sua política de não-demissāo, como também pelas outras medidas voltadas para a fixação do pessoal. Eigher nos ajuda a compreender este dado quando afirma que um receptor submisso durante muito tempo à comunicação paradoxal muito provavelmente adotará este mesmo tipo de pressão na sua relação com os outros. Segundo este autor, "As consequiências são a degradação da lógica simbólica e a impossibilidade de estabelecer uma lógica dos contrários, ou seja, de atingir o conflito". ${ }^{19}$

Enfim, parece-nos importante salientar que a empresa estratégica ${ }^{20}$ não apenas cria, mas mantém uma considerável dependência dos empregados em relação a si própria. Por trás de um discurso que enaltece a liberdade e a democracia, encontramos um universo totalitário ou, no mínimo, totalizante, um universo fechado, que exerce grande influência sobre a vida psíquica dos indivíduos, ao contrário dos 
antigos métodos que tinham no corpo o seu alvo mais importante. No entanto, este universo representa, ao mesmo tempo, uma situação de extremo conforto à medida que ele oferece aos participantes uma espécie de segurança, de certeza e de satisfação narcísea dificilmente encontradas em outras situações de trabalho.

Esse tipo de empresa torna-se um lugar privilegiado, uma referência maior de valores, substituindo outras instituições como a família, a igreja, a escola ou mesmo o sindicato. Tudo isso concorre para a redução considerável da capacidade crítica do sujeito e, conseqüentemente, de suas possibilidades concretas de opor uma resistência a essas políticas. Percebemos que um número importante de empregados forjou uma imagem da empresa como inatacável e perfeita, através de um jogo complexo de idealizações, clivagens e deslocamentos. Isto não quer dizer que os meios de resistência e de reapropriação estejam ausentes, mas constatamos que eles estão bem aquém do que tem sido observado nas empresas que adotam outras políticas.

\section{As dimensões sociológicas}

No plano sociológico, a análise dessas novas práticas gerenciais nos leva a pensar num duplo processo de exclusão: de um lado, a exclusão de uma grande massa de assalariados que não tem acesso às vantagens oferecidas por essas empresas que - apesar de sua importante difusão no decorrer dos últimos anos - são ainda uma minoria, particularmente em função do alto custo dessas políticas; de outro lado, constatamos a auto-exclusão dos próprios empregados dessas empresas em função do seu isolamento num universo tão distante da realidade na qual vive e trabalha a maioria das pessoas. Observamos, entre outras coisas, que os trabalhadores da empresa estudada sentem-se muito distantes das reivindicações mais freqüentemente expressas pela classe operária no Brasil, além de rejeitarem fortemente o sindicato. A antecipação dos conflitos, a hostilidade em relação à ação sindical (mesmo se alguns desses empresários defendem uma política de boas relações com o sindicato) e a tentativa de evitar toda reivindicação coletiva, privilegiando as reivindicações in- dividuais, são aspectos dessas políticas que nos ajudam a compreender melhor este dado.

Diante das evidências oferecidas pela grande parte dos países que adotam essas políticas, até mesmo aqueles que as defendem serão obrigados a admitir que é impossível a sua adoção por todas as empresas, assim como é impossível estender à sociedade como um todo os benefícios que lhes são atribuídos. As conclusões de Gorz nos parecem pertinentes para compreender, pelo menos em parte, o que se passa na nossa sociedade. Este autor constata uma "divisão ou dualismo social" que se opera nas sociedades industrializadas há algum tempo e que lhe parece inevitável. Segundo ele, é uma elite de trabalhadores nessas sociedades que detém o privilégio de ter um emprego, um trabalho mais qualificado, altos salários e maiores possibilidades de formação e promoção. Este privilégio tem como contrapartida, segundo ele, o desemprego, a precariedade do emprego, a desqualificação e a insegurança da maioria. As suas conclusões vêm reforçar as nossas próprias observações: para ele, as empresas tentam fixar uma elite operária da qual elas não podem prescindir, tentando, ao mesmo tempo, "desligá-la de sua classe de origem, conferindo-lhe uma identidade e uma dignidade sociais distintas". E conclui, de uma forma bastante coerente com os nossos próprios resultados, dizendo que esta elite operária "é encorajada a ter seus próprios sindicatos independentes, seus próprios seguros de saúde co-financiados pela empresa, mas que ela terá ao mesmo tempo sua capacidade de negociação e de reivindicação limitadas devido ao seu isolamento e ao seu apego aos privilégios que lhe são concedidos". ${ }^{21}$

Enriquez segue na mesma direção quando afirma que nas empresas estratégicas a implicação dos empregados não significa sua integração, pois o critério de eficácia está bem longe do critério de integração. Suas conclusões coincidem com as nossas: "... trata-se freqüentemente de uma identificação dos trabalhadores com a empresa, com seus objetivos (rentabilidade, eficácia, lucro) e com seus métodos. Neste caso, a alienação é maior à medida que aquilo que é solicitado ao trabalhador não é somente seu trabalho, mas seu ser como um todo, sua afetividade ou até mesmo seu inconsciente". ${ }^{22}$
21. GORZ, A. Métamorphose du travail - la quête du sens. Paris: Galilée, 1988.

22. ENRIQUEZ, E. Rapport de synthèse de Forum de Delphes. Paris: Karphala, 1991. 
23. Estamos empregando o termo integração como uma relação de encontro com o outro, onde ambos os atores são autônomos e conscientes de seus objetivos, decidindo sobre suas ações e sobre os compromissos que desejam assumir. Desta forma, na integração existe um reconhecimento mútuo, um alargamento da esfera da autonomia individual e coletiva pela aceitação da autonomia e da alteridade do outro. A inclusão, ao contrário, pode ser entendida como a ação de um sujeito, a fim de que 0 outro se conforme a uma situação definida por um dos dois atores em jogo. (Ver a este respeito MAPPA, S. et al. Op. cit.).

Uma primeira versão deste texto foi apresentada na XVII Reunião da Anpad, realizada em Salvador, em setembro de 1993.
Pensamos também que essas novas políticas não se apóiam de maneira alguma sobre critérios de integração e que elas provocam de preferência a inclusão dos indivíduos, isto é, a sua conformidade, a uma situação imposta pela empresa. ${ }^{23}$ Nosso estudo, dentre outros, revela que a alienação é fortemente presente nessas empresas, apesar de todo o esforço desenvolvido por elas no sentido de enriquecer o conteúdo do trabalho e de mobilizar os trabalhadores através de uma melhor remuneração, da iniciativa e da participação. As razões dessa alienação são diferentes daquelas encontradas comumente nas empresas tradicionais: ela se mani-

festa, em geral, através da extrema passividade, da ausência de qualquer protesto, associadas a um forte apego aos privilégios concedidos pela empresa, dos quais o sujeito não quer ou não pode mais prescindir.

Em resumo, podemos afirmar que esta nova cultura empresarial não é portadora de nenhuma contribuição, no sentido de proporcionar uma maior integração dos empregados e uma maior democratização da empresa, mas que ela engendra, ao contrário, uma forte relação de dominação, provocando, ao mesmo tempo, processos de exclusão e de auto-exclusão, fonte de novas clivagens, notadamente, na classe trabalhadora.

\section{CONCLUSÃO}

A racionalidade instrumental, fortemente presente - seja nas grandes decisões políticas, seja nas práticas cotidianas da sociedade contemporânea - revela-se e adquire uma solidez cada vez maior na expansão considerável dessas novas práticas gerenciais. No Brasil, a grande aceitação de tais práticas já revela por si só esta perversão da razão que prevalece também entre nós. Através deste artigo, tentamos mostrar como a expansão dessas novas políticas de pessoal permite, na verdade, o desenvolvimento de processos de exclusão e de auto-exclusão em vez de facilitar ou de acompanhar a integração dos empregados, a democratização e a humanização das empresas, apesar de serem estes os conteúdos mais presentes no seu discurso. As conseqüências de tais políticas podem ser ainda mais graves numa sociedade como a nossa, onde os mecanismos de regulação dessa racionalidade instrumental, quando eles existem, permanecem ainda pouco desenvolvidos. Pensamos, como exemplos destes mecanismos reguladores, na maior presença de instituições democráticas ou no maior acesso à cidadania, suscetíveis, em nossa opinião, de exercer um certo controle sobre os efeitos perversos desta racionalidade. Além disso, poderíamos nos interrogar, a partir da extrema instabilidade econômica na qual vivemos há bastante tempo, se esta precariedade contínua não tornaria os assalariados brasileiros ainda mais frágeis se comparados aos assalariados do Primeiro Mundo. Tudo isso para dizer que essas novas políticas de pessoal, importadas pelas empresas brasileiras, podem apresentar conseqüências bem mais graves no nosso contexto do que aquelas já explicitadas por numerosas análises realizadas nos países que as conceberam.

Nossa intenção neste artigo era a de propor uma discussão sobre as prováveis conseqüências da expansão cada vez mais importante dessas novas práticas gerenciais no Brasil. Tentamos tratar a questão tanto nas suas dimensões psicológicas quanto sociológicas, mas gostaríamos de prevenir o leitor de que não tivemos a pretensão de esgotar o assunto, mas somente de propor algumas pistas de reflexão que poderão ser retomadas posteriormente através de um amplo debate de idéias. 